\title{
A GIS modelling framework to evaluate marine spatial planning scenarios: Co-location of offshore wind farms and aquaculture in the German EEZ
}

\author{
Antje Gimpel ${ }^{\mathrm{a}, *}$, Vanessa Stelzenmüller ${ }^{\mathrm{a}}$, Britta Grote ${ }^{\mathrm{b}}$, Bela H. Buck ${ }^{\mathrm{b}}$, Jens Floeter ${ }^{\mathrm{c}}$, \\ Ismael Núñez-Riboni ${ }^{a}$, Bernadette Pogoda ${ }^{b}$, Axel Temming ${ }^{c}$ \\ a Thünen Institute (TI), Federal Research Institute for Rural Areas, Forestry and Fisheries, Institute of Sea Fisheries, Palmaille 9, 22767 Hamburg, Germany \\ ${ }^{\mathrm{b}}$ Alfred Wegener Institute Helmholtz Centre for Polar and Marine Research (AWI) Bussestrasse 27, 27570 Bremerhaven, Germany \\ ${ }^{\mathrm{C}}$ Institute for Hydrobiology and Fisheries Science, University of Hamburg, Olbersweg 24, 22767 Hamburg, Germany
}

\section{A R T I C L E I N F O}

\section{Article history:}

Received 29 August 2014

Received in revised form

26 January 2015

Accepted 26 January 2015

\section{Keywords:}

Aquaculture

Co-location

GIS

Marine Spatial Planning

Offshore Site Selection

Wind farms

\begin{abstract}
A B S T R A C T
The concept of co-location of marine areas receives an increased significance in the light of sustainable development in the already heavily used offshore marine realm. Within this study, different spatial colocation scenarios for the coupling of offshore aquacultures and wind farms are evaluated in order to support efficient and sustainable marine spatial management strategies. A Geographic Information System (GIS) and multi-criteria evaluation (MCE) techniques were combined to index suitable co-sites in the German exclusive economic zone of the North Sea. The MCE was based on criteria such as temperature, salinity or oxygen. In total, 13 possible aquaculture candidates (seaweed, bivalves, fish and crustaceans) were selected for the scenario configuration. The GIS modelling framework proved to be powerful in defining potential co-location sites. The aquaculture candidate oarweed (Laminaria digitata) revealed the highest suitability scores at $10-20 \mathrm{~m}$ depth from April to June, followed by haddock (Melanogrammus aeglefinus) at 20-30 m depth and dulse (Palmaria palmata) and Sea belt (Saccharina latissima) at 0-10 m depth between April and June. In summary, results showed several wind farms were de facto suitable sites for aquaculture since they exhibited high suitability scores for Integrated MultiTrophic Aquaculture (IMTA) systems combining fish species, bivalves and seaweeds. The present results illustrate how synergies may be realised between competing needs of both offshore wind energy and offshore IMTA in the German EEZ of the North Sea. This might offer guidance to stakeholders and assist decision-makers in determining the most suitable sites for pilot projects using IMTA techniques.
\end{abstract}

(c) 2015 Elsevier Ltd. All rights reserved.

\section{Introduction}

Given the heavy exploitation of wild fish stocks in combination with an increasing demand for aquatic products, offshore aquaculture production may contribute to food security and relief some of the pressures on wild stocks. However, to deliver on these promises and secure production well into the future, further attention needs to be paid to the increasing requirements for water resources as well as market demands, logistics and technical developments [1,2]. Aquaculture poses a conflict potential in combination with other

\footnotetext{
* Corresponding author. Tel.: +494038905 272.

E-mail addresses: Antje.Gimpel@ti.bund.de (A. Gimpel) vanessa.stelzenmueller@ti.bund.de (V. Stelzenmüller), Britta.Grote@awi.de (B. Grote),Bela.H.Buck@awi.de (B.H. Buck), jfloeter@uni-hamburg.de (J. Floeter),

Ismael.Nunez-Riboni@ti.bund.de (I. Núñez-Riboni),

Bernadette.Pogoda@awi.de (B. Pogoda), atemming@uni-hamburg.de (A. Temming).
}

(traditional) activities such as fisheries or tourism by competing on space [3]. With an increase of designated areas for offshore wind development, planned until 2025, the race for space will gain more importance in offshore and coastal waters of the German North Sea. Fisheries are at risk of losing access to traditional fishing grounds due to the safety requirements imposed by wind farm development, leading to potentially decreased landings [4]. Competition for maritime space and the need for sustainable food production highlight the importance of efficient adaptive management, to avoid potential conflicts as well as create synergies between different activities [1,57]. Considering the recent European Maritime Spatial Planning (MSP) Directive, the implementation of Blue Growth, a long term strategy promoted by MSP to support sustainable growth in the marine environment, is required by 2020 [8]. In the light of Good Environmental Status (GES) requirements of the Marine Strategy Framework Directive (MSFD), different uses made of the marine resources should be conducted at a sustainable level, individually as well as cumulatively [9]. Therefore, the concept of co-location (also referred to as 
co-use or multi-use [10]) of marine offshore areas currently receives increased significance [11]. The possibility of co-location depends on site specific characteristics and adaptive management $[3,12]$. In this field, case studies are essential to explore co-location-options, like [13] for offshore aquaculture in combination with wind farms in Danish waters or by [11] as well as [14] for co-management options and legal constraints for offshore aquaculture possibilities in German waters. According to [15], not only the research community but also the policy makers are interested in 'sustainable, resource- and spaceefficient solutions'. Further, stakeholders' apprehensions are generally referred to biological, economical or technological issues, which need to be eliminated using concrete, transparent tools or, even better, pilot projects for research. Besides, regulations for aquaculture in Offshore Wind Farm (OWF) areas are unclear or even completely lacking [11].

Within the interdisciplinary project Offshore Site Selection (OSS), a co-location roadmap is generated for future uses (existing and further) of marine areas in German waters to regulate and reduce the impact on the ecosystem $[10,16]$. One objective constitutes the definition of potential areas in the German Exclusive Economic Zone (EEZ) of the North Sea for the co-utilisation of OWFs and Integrated Multi-Trophic Aquaculture (IMTA).

IMTA systems combine aquaculture species to recycle effluent dissolved and particulate nutrients from a higher trophic-level species (fish) to nourish extractive, lower trophic-level species, such as filter feeders (mussels, oysters), polychaetes, sea cucumbers and/or seaweed $[17,18]$. These systems aim at balanced nutrient budgets and minimize the waste production originating from fed aquaculture species through the filtering capacity of other extractive species clearing the water [19]. Moreover, by using nutrient losses of higher trophic-level species as feeding products, IMTA could provide additional economic benefits [17]. Concerning the GES standards given by the European Commission [9], IMTA systems intend to maintain the functioning and resilience of ecosystems while aiming to prevent the decline of biodiversity such as wild fish stocks caused by human activities [20].

Selecting offshore areas for IMTA brings advantages such as enhanced water quality due to higher levels of dissolved oxygen, less impact by other human activities and opportunities to increase the scale and expansion for aquaculture [11,13,19,21,22]. In spite of the risks (currents, strong wave action, harsh offshore wind conditions) and disadvantages (increasing environmental costs in comparison to onshore aquaculture due to logistics) [19], offshore aquacultures have already been successfully undertaken for haddock, halibut and mussels in the US waters [23] as well as oysters and mussels within the German Bight [24]. There can be positive effects concerning shared logistics and infrastructure and restrictions for other types of activities due to the security zone around the OWFs. Further, next to 'room-in-room-solutions' the provision of OWFs structures to build on has been discussed $[11,13,25,26]$, though, according to $[27,13]$, this purpose would require alterations to OWF technologies. As this not only leads to increased costs, but also to extraordinary forces acting upon aquaculture cages and potentially destroying OWF structures, latest plans do refrain from banking on such doubled benefits.

This study contributes to the indexation of potential areas for the co-location of OWF areas and offshore aquacultures in a spatiotemporal manner. The suitable sites were identified in application of a Geographic Information System (GIS) based Multi-Criteria Evaluation (MCE), which has been previously used for land based site selection by [28-30] and for offshore site selection by [31]. Subsequently, different approaches to criteria aggregation were examined by using the Ordered Weighted Averaging (OWA) technique [32]. In this way, the risk of making the wrong decision in aggregating the criteria which determine the suitability of aquaculture sites has been addressed. Using the GIS MCE led to continuous scaling between the risk averse and risk taking OWA operators [30,33], providing basic decision scenarios for the evaluation of co-locations in the German EEZ of the North Sea. The study does not account for environmental carrying capacity or environmental impacts, nor does it consider economic viability both of which will influence the success of any offshore aquaculture development.

In this paper, the procedure as well as the main findings of the GIS-based modelling framework (Fig. 1) are summarised to demonstrate the applicability of the methodological approach in a marine ecosystem. Finally, the different spatial co-location scenarios for the coupling of offshore aquacultures and OWF areas are evaluated in order to explore the practical application of colocated offshore aquacultures in combination with OWFs.

\section{Material and methods}

\subsection{Case study specifications}

The study area comprised the German EEZ of the North Sea with a surface area of $28,539 \mathrm{~km}^{2}$ (Fig. 2). Next to other uses, the main human activities regulated by the German MSP are shipping, oil and gas exploitation, cables and pipelines, renewable energy development, and aggregate extraction [11,35]. The allocation of fishing activities is not included in the German MSP [4,36,37]. Currently, marine aquaculture is only taking place nearshore in terms of mussel and oyster cultures within the Wadden Sea National Park. Offshore cultivation is currently conducted in various pilot studies, however, it is not yet done at commercial scale $[11,14]$.

The respective study area was subdivided into a set of grid cells accounting for the spatial resolution of available data and computation time. This revealed a grid size resolution of $9.26 \mathrm{~km}^{2}$. Within this study, the terms offshore, onshore and nearshore were applied as follows: offshore is beyond $12 \mathrm{~nm}$ from the shoreline, nearshore (and coastal/inshore) is between $12 \mathrm{~nm}$ and shoreline and onshore is $3 \mathrm{~km}$ inland from the shoreline.

\subsection{Aquaculture candidates and environmental criteria}

In total, 21 species of seaweed, bivalves, fish, and crustaceans were identified as adequate aquaculture candidates accounting for their native occurrence in the German North Sea, their resistance to hydrodynamic conditions in offshore environments as well as their economic potential for the EU market. From those, the 13 most promising ones were selected for the scenario configuration. From the literature and experimental data, parameters have been selected for the targeted species (Table 1 ). In order to provide a fundamental data base of environmental variables, hydrographic data from 2002 to 2012 were extracted from National Oceanic and Atmospheric Administration (NOAA) and combined with data provided by the Federal Maritime and Hydrographic Agency (BSH), covering the entire German EEZ of the North Sea: temperature $\left({ }^{\circ} \mathrm{C}\right)$, salinity (PSU), nitrate/nitrite $\left(\mathrm{NO}_{2}^{-} / \mathrm{NO}_{3}^{-}[\mu \mathrm{M} / \mathrm{L}]\right)$, chlorophyll a $(\mu \mathrm{g} / \mathrm{L})$, oxygen $(\mathrm{ml} / \mathrm{L})$ and ammonium $\left(\mathrm{NH}_{4}^{+}[\mu \mathrm{M} / \mathrm{L}]\right)$. Because preferences of selected candidates may differ with respective depth layers (Table 1 ) and time scales, gaps in the vertical profiles of the water column were filled as follows:

An average profile for each variable was calculated with all available data in a yearly quarter. This average profile was displaced to minimise the sum of squared differences between average and individual (gappy) profiles. Missing values in the individual profiles were replaced by values of the displaced average profile at the corresponding depth. As the raw data of ammonium were insufficient from April to June, no interpolation was possible.

To complete the set of environmental variables, modelled current velocity (m/s) data from 1958 to 2004 and wave height (m) data 


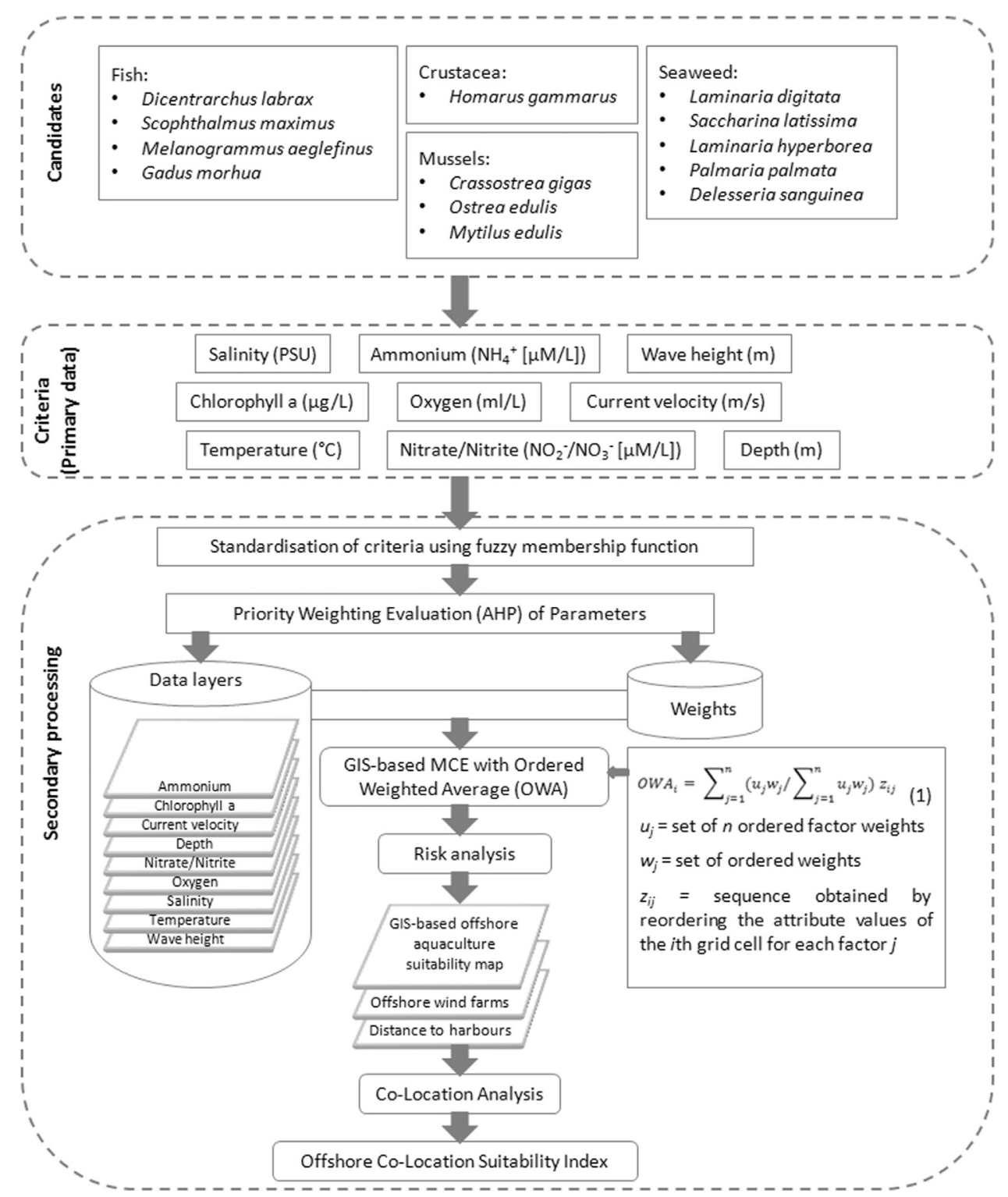

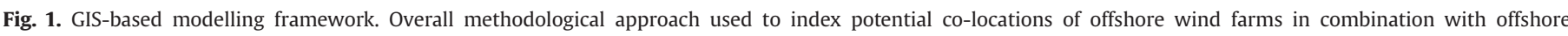
aquaculture, adapted from [34].

from 1958 to 2007 [38] were used to derive depth stratified mean values per quarter to account for seasonality (1st quarter from January to March; 2nd quarter from April to June, etc.).

To generate the criteria for the GIS MCE, the environmental variables were interpolated onto a regular grid encompassing the southern part of the North Sea with universal kriging (Fig. 3). Empirical variograms were calculated and theoretical variogram functions were fitted using weighted least squares, accounting for directional influences, i.e. trends and anisotropy. The fitted omnidirectional and directional Gaussian, spherical or exponential covariance models were examined with the help of cross validation and a Goodness of Fit (GOF) parameter yielding the best fitting models [31,32].

\subsection{Standardisation and priority weighting of criteria}

The criteria were standardised on a scale of $1-10(10=$ high suitability) using fuzzy membership functions [39]. The function selected governed the shape of the suitability curve and the control points restricted its start/end (Table 1). In other words, the starting point represents the inflection point as the membership function rises above 0 . For example, current velocity for oarweed (Laminaria digitata) starts to be suitable at $0.51 \mathrm{~m} / \mathrm{s}$ for this species. At $1 \mathrm{~m} / \mathrm{s}$ and with a suitability of 10 the peak of the bell-shaped fuzzy membership function is approached, at $1.48 \mathrm{~m} / \mathrm{s}$ the suitability falls below 1 again, and finally approaches 0 at the end point of $1.54 \mathrm{~m} / \mathrm{s}$. Consequently, current velocity below 0.51 and above $1.54 \mathrm{~m} / \mathrm{s}$ gained a suitability of 0 during the standardisation procedure for $L$. digitata. The choice of function and control points was based on expert knowledge and literature research.

The pairwise comparison method of the Analytical Hierarchy Process (AHP) was used to weight the factors (standardised criteria) by priority [30,55]. The weighting of the factors was based on optimal growth under farmed conditions and was judged by experts. The pairwise comparison matrix (Table 2) employs an underlying scale from "less important" to "more important". Importance is rated on a nine point continuous scale. Scaling temperature and wave height equally, as done for $L$. digitata, both factors would be rated with 1 . Scaling wave height as "moderately more important" than salinity, the factor wave height would be rated with 3 and the factor salinity with 0.3 . These preferences are 


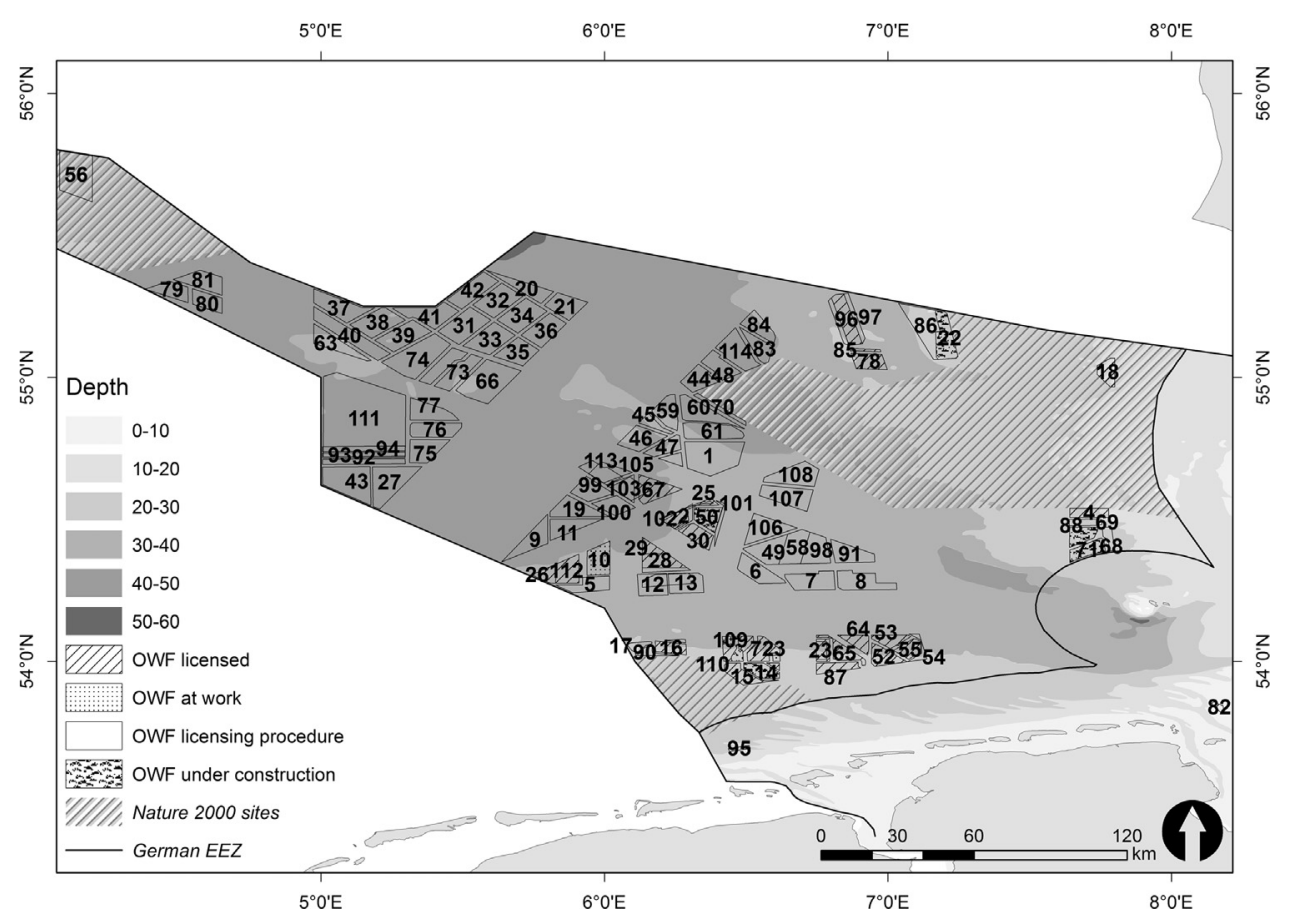

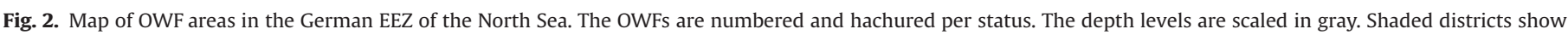

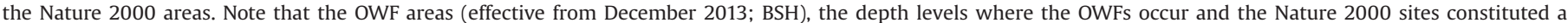

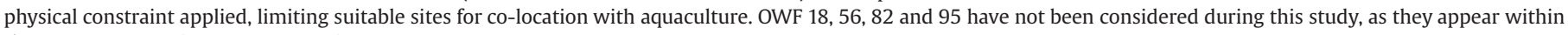
the $12 \mathrm{~nm}$ zone or in Nature 2000 sites.

summarised by normalising the eigenvector associated with the maximum eigenvalue of the pairwise comparison matrix. The eigenvector then gives the relative weights of the factors. Furthermore, the Consistency Ratio (CR) to measure the degree of consistency in judgement of the pairwise comparison was calculated: if $\mathrm{CR}<0.1$, the ratio indicates a reasonable level of consistency [33].

Considering the lacking information about ammonium, the weighting for the second quarter has been calculated excluding this factor. This exclusion was applied for various fish species, such as Atlantic cod (Gadus morhua), European sea bass (Dicentrarchus labrax), haddock (Melanogrammus aeglefinus), turbot (Scophthalmus maximus) and one seaweed species, the sugar kelp (Saccharina latissima). Furthermore, the factor wave height has a minor impact at depths below $10 \mathrm{~m}$ and was exempted from all weightings for depth layers below $10 \mathrm{~m}$. Next to these factors, physical constraints such as the appropriate depth (m) for each candidate as well as the Nature 2000 areas [56] (excluding human activities) were applied, defining the area suitable for co-location.

\subsection{GIS-based Multi-Criteria Evaluation (MCE) with Ordered Weighted Averaging (OWA) technique}

Using the OWA, a range of weighting designs were modelled to address the risk of making the wrong decision in aggregating the factor values determining the suitability of aquaculture sites. The OWA is a family of multi criteria combination procedures:

$O W A_{i}=\sum_{j=1}^{n}\left(u_{j} w_{j} / \sum_{j=1}^{n} u_{j} w_{j}\right) z_{i j}$

where $u=\left(u_{1}, \ldots, u_{j n}\right)$ is the set of $n$ ordered factor weights (based on expert knowledge) for individual global weighting; $w=\left(w_{1}, \ldots\right.$, $w_{n}$ ) is the set of ordered weights for individual local weighting; and $z_{i}=\left(z_{i 1}, \ldots, z_{i n}\right)$ is the sequence obtained by reordering the values of the $i$ th grid cell for each factor $j$ [32]. An example for $L$. digitata, where the factor values $(4,2,8,3)$ were associated with the factor weights $(0.3,0.3,0.3$ and 0.1 ; Table 2$)$ : According to a descending order of the factor values $z(8,4,3,2)$ the corresponding weights were then reordered $(u=0.3,0.3,0.1,0.3)$ per grid cell and subsequently combined with a set of ordered weights $w$. Following [32], Regular Increasing Monotone (RIM) quantifiers $\alpha$ (Table 3 ) were used to generate the ordered weights $w$. Including these RIM quantifiers $\alpha$, the OWA is redefined [32]:

$\mathrm{OWA}_{i}=\sum_{j=1}^{n}\left(\left(\sum_{k=1}^{j} u_{k}\right)^{\alpha}-\left(\sum_{k=1}^{j-1} u_{k}\right)^{\alpha}\right) z_{i j}$

for $k=1,2, \ldots, l ; l \leq n$.

Two features can be used to characterise the OWA operators. The first is the attitudinal character (ORness). The ORness represents the degree of risk to misinterpret factor attributes (on a scale of 0 to 1) and can be achieved through Eq. (3):

ORness $=1-\left(\frac{1}{n-1} \sum_{r}(n-r) w_{r}\right)$

where $n$ is the number of factors, $r$ is the order of factors, and $w_{r}$ is the weight for the factor of the $r$ th order [30]. The ORness can be specified using $\alpha[32,33,55]$. More precisely, by changing $\alpha$, different degrees of ORness can be obtained: Using the previous example of $L$. digitata, a quantifier of $\alpha=0.0001$ (OR operator) would result in a set of OWA weights $=1,0,0,0$ (Table 3). The OWA value of the respective grid cell would then be 8 but the ORness would result in 1 , as a maximum of risk underestimating the factor attributes (i.e. low factor values) is reached.

The second feature to characterise the OWA operators is the degree of dispersion (Tradeoff). The Tradeoff, on a scale of $0-1$, represents to which level a good performance of one factor can substitute a poor performance of another factor (compensation). 
Table 1

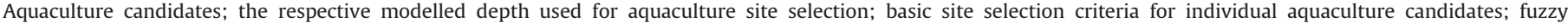
membership functions with corresponding parameterisation (start/end points) based on literature research and expert knowledge; modified after [39] ${ }^{\text {. }}$

\begin{tabular}{llllll}
\hline Aquaculture candidates & $\begin{array}{l}\text { Modelled } \\
\text { depth }\end{array}$ & $\begin{array}{l}\text { Basic criteria for } \\
\text { site-selection }\end{array}$ & $\begin{array}{l}\text { Parameterisation } \\
\text { (start and end } \\
\text { points) }\end{array}$ & $\begin{array}{l}\text { Fuzzy membership } \\
\text { function (sigmoidal) }\end{array}$ & Reference
\end{tabular}

\section{Fish} (Dicentrarchus labrax) $\quad 20-30 \mathrm{~m}$

Turbot (Scophthalmus maximus)

20-30 m Current velocity $(\mathrm{m} / \mathrm{s})$

30-40 m Oxygen $(\mathrm{ml} / \mathrm{L}) \quad 3.5$

$40-50 \mathrm{~m}$

Salinity (PSU) 10

Temperature $\left({ }^{\circ} \mathrm{C}\right) \quad 12$

Haddock (Melanogrammus aeglefinus)

10-20 m Ammonium $(\mu \mathrm{M} / \mathrm{L}) \quad 0$

20-30 m Current velocity $(\mathrm{m} / \mathrm{s}) \quad 0.3$

$30-40 \mathrm{~m}$

40-50 m

Oxygen $(\mathrm{ml} / \mathrm{L})$

Salinity (PSU) 31

Temperature $\left({ }^{\circ} \mathrm{C}\right) \quad 1$

Atlantic cod (Gadus morhua)

$10-20 \mathrm{~m} \quad$ Ammonium $(\mu \mathrm{M} / \mathrm{L}) \quad 0$

20-30 m Current velocity $(\mathrm{m} / \mathrm{s}) \quad 0$

30-40 m Oxygen $(\mathrm{ml} / \mathrm{L}) \quad 2.45$

$40-50 \mathrm{~m}$

Crustacea

European lobster (Homarus $30-40 \mathrm{~m}$ gammarus)

40-50 m

$\begin{array}{ll}\text { Salinity (PSU) } & 8 \\ \text { Temperature }\left({ }^{\circ} \mathrm{C}\right) & 1\end{array}$

Current velocity $(\mathrm{m} / \mathrm{s}) \quad 0$

Oxygen $(\mathrm{ml} / \mathrm{L}) \quad 1$

Salinity (PSU) 20

Temperature $\left({ }^{\circ} \mathrm{C}\right) \quad-1$

Wave height $(\mathrm{m})^{\mathrm{a}} \quad 0$

Bivalves

Pacific oyster (Crassostrea gigas)

10-20 m

Chlorophyll a $(\mu \mathrm{g} / \mathrm{L})$

Current velocity $(\mathrm{m} / \mathrm{s}) \quad 0.1$

Oxygen (ml/L) 2

Salinity (PSU) 10

$\begin{array}{ll}\text { Temperature }\left({ }^{\circ} \mathrm{C}\right) & -1 \\ \text { Wave height }(\mathrm{m})^{\mathrm{a}} & 0\end{array}$

European oyster (Ostrea edulis

Chlorophyll a $(\mu \mathrm{g} / \mathrm{L}) \quad 0$

Current velocity $(\mathrm{m} / \mathrm{s}) \quad 0.1$

0-10 m Oxygen $(\mathrm{ml} / \mathrm{L}) \quad 2$

10-20 m Salinity (PSU) 18

Temperature $\left({ }^{\circ} \mathrm{C}\right) \quad 0$

Wave height $(\mathrm{m})^{\mathrm{a}} \quad 0$

Blue mussel (Mytilus edulis

0-10 m Chlorophyll a $(\mu \mathrm{g} / \mathrm{L}) \quad 0$

$10-20 \mathrm{~m} \quad$ Current velocity $(\mathrm{m} / \mathrm{s}) \quad 0.51$

Oxygen $(\mathrm{ml} / \mathrm{L})$

Salinity (PSU) 18

Wave height $(\mathrm{m})^{\mathrm{a}} \quad 0$

\section{Seaweed}

Oarweed (Laminaria digitata)

Sugar kelp (Saccharina latissima)

\section{hyperborea)}

Cuvie (Laminaria

Dulse (Palmaria palmata)

Current velocity (m/s) 0.51

$0-10 \mathrm{~m}$

10-20 m

Temperature $\left({ }^{\circ} \mathrm{C}\right)-1$

Wave height $(\mathrm{m})^{\mathrm{a}} \quad 0$

Ammonium $(\mu \mathrm{M} / \mathrm{L}) \quad 0$

Current velocity $(\mathrm{m} / \mathrm{s}) \quad 0.08$

0-10 m Nitrate/Nitrite $(\mathrm{mg} / \mathrm{L}) \quad 3$

10-20 m

Salinity (PSU)

Temperature $\left({ }^{\circ} \mathrm{C}\right) \quad 10$

Wave height $(\mathrm{m})^{\mathrm{a}} \quad 0$

0-10 m Current velocity (m/s) 0.51

10-20 m

Salinity (PSU)

Temperature $\left({ }^{\circ} \mathrm{C}\right)$

Wave height $(\mathrm{m})^{\mathrm{a}} \quad 0$

Current velocity (m/s) 0.51

0-10 m

Salinity (PSU)

0.5
30

10-20 m

Wave height $(\mathrm{m})^{\mathrm{a}}$

100

2

28

100

0.5

$\infty$

35

18

100

0.9

$\infty$

35

20

100

2

$\infty$

23

0.25

$\infty$

40

3

0.8

$\infty$
35

35

$\infty$

0.8

$\infty$

40

19

1.54

$\infty$

32
29

40

22

20

1.52

30

35

6.4

1.54

40

20

4

1.54

40

17

4
Monotonically decreasing Monotonically decreasing

Monotonically increasing

Bell shaped

Monotonically increasing

Monotonically decreasing

Monotonically decreasing

Monotonically increasing

Bell shaped

Bell shaped

Monotonically decreasing

Bell shaped

Monotonically increasing

Bell shaped

Bell shaped

Monotonically decreasing Monotonically decreasing Monotonically increasing

Bell shaped

Bell shaped

Monotonically decreasing Monotonically increasing

Bell shaped

bell shaped

Monotonically decreasing

Monotonically increasing Bell shaped

Monotonically increasing

Bell shaped

Bell shaped

Monotonically decreasing

Monotonically increasing Bell shaped

Monotonically increasing

Bell shaped

Bell shaped

Monotonically decreasing

Monotonically increasing bell shaped

Monotonically increasing

Bell shaped

Bell shaped

Monotonically decreasing

Bell shaped

Monotonically increasing

Bell shaped

Monotonically decreasing

Bell shaped

Bell shaped

Bell shaped

Monotonically increasing

Bell shaped

Monotonically decreasing

Bell shaped

Bell shaped

Bell shaped

Monotonically decreasing

Bell shaped

Bell shaped

Bell shaped

Monotonically decreasing
FAO [40]

Moksness, Kjorsvik [41], Person-Le Ruyet, Buchet [42],

Daniels and Watanabe [43]

Moksness, Kjorsvik [41], Chambers and Howell [44]

Moksness, Kjorsvik [41], Chambers and Howell [44], Jobling [45]

Rosenberg, Hellmann [46], MarLIN [47]

Pogoda, Buck [24], MarLIN [47]

Pogoda, Buck [24], MarLIN [47], Cano, Rosique [48]

Buck [22], MarLIN [47], Karayücel and Karayücel [49]

MarLIN [47], Mc Hugh [50], Bolton and Lüning [51], Lüning [52]

MarLIN [47], Bolton and Lüning [51], Lüning [52], Buck and Buchholz [53]

Mc Hugh [50], Bolton and Lüning [51], Lüning [52

MarLIN [47], Mc Hugh [50], Lüning [52], Werner and Dring [54] 
Table 1 (continued)

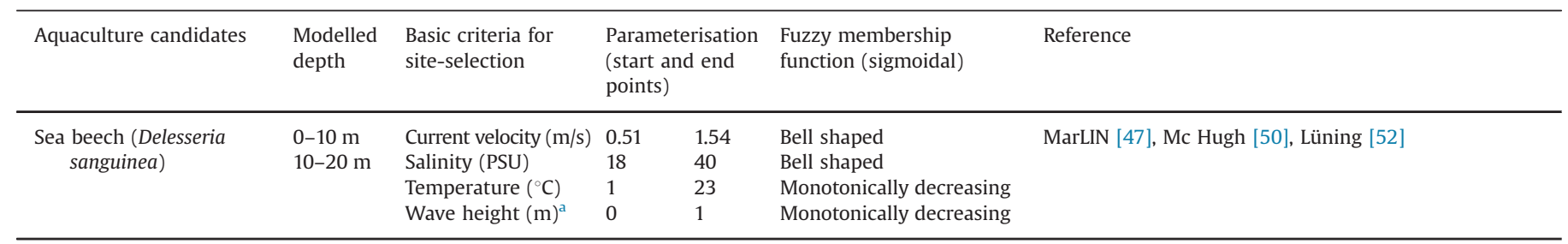

a Note: wave height was not considered below $10 \mathrm{~m}$.

The Tradeoff can be obtained through Eq. (4):

Tradeoff $=1-\sqrt{\left(n \sum_{r}\left(w_{r}-1 / n\right)^{2}\right) / n-1}$

where $n$ is the number of factors, $r$ is the order of factors, and $w_{r}$ is the weight for the factor of the $r$ th order [30]. The Tradeoff depends on the weights distributed across all factors used in a weighting combination [29,30,32,33]. Full compensation would result in a Tradeoff of $1[30,55]$. Within this study, choosing a quantifier of $\alpha=100$ (AND operator) leads to a Tradeoff of 0 , because the performance of the factor weight cannot be compensated by other OWA weights. Choosing an $\alpha$ of 1 results in OWA weights equal to a weighted linear combination (WLC) and therefore to the same weighting scheme as given by expert opinion $(0.3$, $0.3,0.1,0.3$ ) in Section 2.3. Here, with 0.8 a high Tradeoff degree and therefore nearly full compensation would be reached. Choosing an $\alpha$ of 100 leads to the most conservative approach of estimating factor values as the factor limiting the suitability (i.e. the lowest one) is weighted discretely. However, the degree of dispersion would then be 0 , too, as there can be no compensation of the performance by other OWA factor weights.

\subsection{Risk and co-location analysis}

The aquaculture suitability modelling resulted in a compilation of geo-referenced layers between the risk averse (AND) and the risk taking (OR) OWA operators comprising the whole German EEZ of the North Sea. Within this study, two scenarios have been regarded as determinative: the AND scenario, which can be seen as the most conservative approach, where the factor attribute limiting the suitability was weighted discretely; and the WLC scenario, where the OWA weights were equal to the weights determined by experts based on optimal growth under farmed conditions (see Section 2.3).

A combination of both weighting designs was used during risk analysis. With the aim to define a low degree of risk (ORness) estimating the factor attributes disproportionately and a low degree of compensation (Tradeoff) between the factor weights, the $\alpha$ parameter was raised up to 100 (AND operator). Thus, the grid cells containing factor values of 0 were identified and excluded from further assessments. To calculate the optimal growth under farmed conditions, $\alpha$ was specified as 1 (WLC operator), and the factor values were weighted on the base of expert opinion (as previously done by using the AHP) for the remaining grid cells. In other words, only if one cell was indexed as suitable during the risk analysis, compensation was allowed and the WLC score was recorded for the GIS-based offshore aquaculture suitability map.

Accounting for the spatial overlap of the aquaculture suitability layers with the respective geo-referenced OWF areas provided by the BSH (effective from December 2013), an offshore co-location suitability index has been developed. As the study area comprised the German EEZ of the North Sea, OWF areas outside of the EEZ (or inside the $12 \mathrm{~nm}$ zone) were not considered.
Within this study, the scenarios and suitability scores have not only been stratified by depth, moreover the seasonality has been accounted for. The reason is that some aquaculture candidates might be cultivated onshore and reared offshore at a stadium when getting more resilient. As offshore aquaculture leads due to logistics to increasing environmental costs in comparison to onshore and land based aquaculture, the factor distance of the OWF areas to the next harbour has been incorporated.

\section{Results}

\subsection{Standardisation and priority weighting of criteria}

The factor values resulting out of the standardisation process revealed multiple limitations in sites suitable for aquaculture. Most limitations for species such as S. maximus or European lobster (Homarus gammarus) were the result of low (maximum) parameterisations for current velocity. Further, the maximum parameterisation of temperature or wave height, especially in the case of sea beech (Delesseria sanguine), led to limited suitability.

With $\mathrm{CR}<0.1$ the priority weighting revealed fair results for all fish species (D. labrax, S. maximus, M. aeglefinus, G. morhua), H. gammarus and all seaweed species (L. digitata, S. latissima, cuvie Laminaria hyperborea, dulse Palmaria palmata, D. sanguinea). Whe reas the pairwise comparison for all bivalve species (blue mussel Mytilus edulis, European oyster Ostrea edulis and Pacific oyster Crassostrea gigas) revealed a CR of 0.14 , indicating an imbalanced weighting composition of the respective optimal growth factors [33]. Leaving out the factor wave height at $10-20 \mathrm{~m}$ depth, a CR of 0.03 was assessed.

\subsection{GIS-based Multi-Criteria Evaluation (MCE) with Ordered Weighted Averaging (OWA) technique}

Different spatial co-location scenarios were constructed by using a range of aggregation approaches, i.e. OWA operators (Fig. 4). Changing the $\alpha$ parameter and therefore the order weights of various factors led to multiple levels of risk (ORness) over- or underestimating individual factor attributes. In addition, it leads to several degrees of compensation (Tradeoff) between the factor weights. For all candidates, the AND scenario has been characterised by zero values in the case of both, the level of risk as well as the degree of compensation.

Weighting $L$. digitata, the degree of dispersion between the factor weights approached nearly full compensation $(=0.8)$ when $\alpha$ was set to 1 , whereas the risk level was assessed as 0.53 . Calculating these features for S. latissima resulted in a risk level of 0.47 and a compensation of 0.82 . Full compensation $(=1)$ in combination with a low risk level $(=0.5)$ was reached by weighting all factors equally as done for P. palmata and L. hyperborea. When assessing the candidates $D$. sanguine and H. gammarus, the compensation resulted in 0.67 and the risk level of 0.56 . 

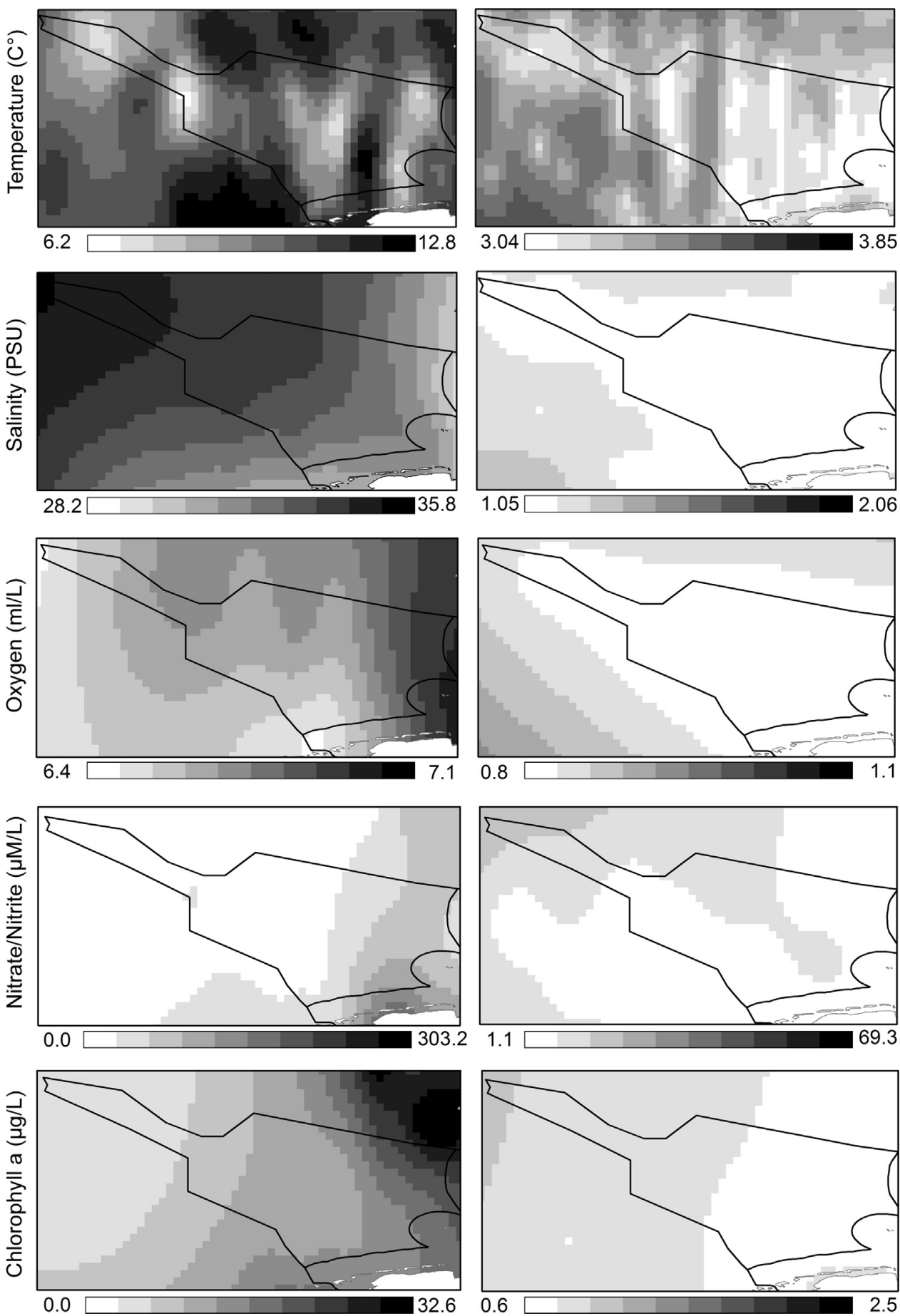

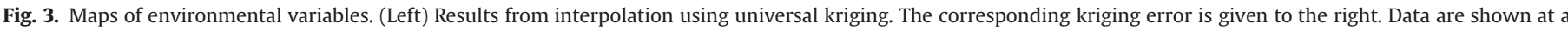
depth of 0-10 m and from the 2nd quarter (between 1st of April and 30th of June) in the German EEZ of the North Sea.

Calculating these features for all bivalve species resulted in a compensation of 0.77 and a risk level of 0.43 . The lowest value $(=0.39)$ was obtained when assessing the risk level for S. maximus, the compensation resulted in 0.78 . The same level of compensation was calculated for $D$. labrax, while the degree of risk resulted in 0.5. When assessing the aquaculture candidates G. morhua and M. aeglefinus, a compensation of 0.76 and a risk level of 0.49 were reached.

All other scenarios obtained by using the OWA operators resulted in intermediate degrees of risk and compensation between the OR and the AND scenario (Table 3).

\subsection{Risk and co-location analysis}

As described in Section 2.5, only those grid cells were recorded for the GIS-based offshore aquaculture suitability map, which have been indexed as suitable during the risk analysis. This procedure meant a loss of suitable aquaculture sites for most of the candidates. When the offshore co-location suitability index was developed by accounting for (i) overlaps between the aquaculture sites and the OWF areas and (ii) distance of the OWF to the next harbour, the actual extent of loss became visible: 
Table 2

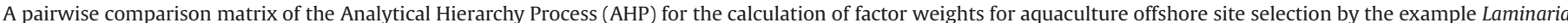

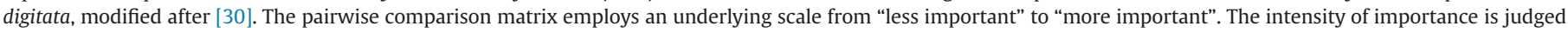
by priority ratings, which are provided on a nine point continuous scale. The consistency ratio $(\mathrm{CR})<0.1$ indicates consistent judgements.

\begin{tabular}{|c|c|c|c|c|c|c|c|c|c|}
\hline & \multicolumn{4}{|c|}{ Less important } & \multicolumn{5}{|c|}{ More important } \\
\hline & $\begin{array}{l}1 / 9 \\
\text { Extreme }\end{array}$ & $\begin{array}{l}1 / 7 \\
\text { Very strong }\end{array}$ & $\begin{array}{l}1 / 5 \\
\text { Strong }\end{array}$ & $\begin{array}{l}1 / 3 \\
\text { Moderate }\end{array}$ & $\begin{array}{l}1 \\
\text { Equal }\end{array}$ & $\begin{array}{l}3 \\
\text { Moderate }\end{array}$ & $\begin{array}{l}5 \\
\text { Strong }\end{array}$ & $\begin{array}{l}7 \\
\text { Very strong }\end{array}$ & $\begin{array}{l}9 \\
\text { Extreme }\end{array}$ \\
\hline Environmental factors & & & & $E_{1}$ & $E_{2}$ & $E_{3}$ & $E_{4}$ & Weights & $C R$ \\
\hline Temperature $\left(E_{1}\right)$ & & & & 1.00 & 1.00 & 1.00 & 3.00 & 0.30 & 0.00 \\
\hline Wave height $\left(E_{2}\right)$ & & & & 1.00 & 1.00 & 1.00 & 3.00 & 0.30 & \\
\hline Current velocity $\left(E_{3}\right)$ & & & & 1.00 & 1.00 & 1.00 & 3.00 & 0.30 & \\
\hline Salinity $\left(E_{4}\right)$ & & & & 0.33 & 0.33 & 0.33 & 1.00 & 0.10 & \\
\hline$\sum$ & & & & 3.33 & 3.33 & 3.33 & 10.00 & & \\
\hline
\end{tabular}

Table 3

Ordered Weighted Average (OWA) operators; fuzzy quantifiers and order weights used to control levels of ORness (risk underestimating factor values) and Tradeoff (compensation between factor values) for the factors predicting suitable sites for Laminaria digitata, modified after [32,29].

\begin{tabular}{llllll}
\hline Operator & Quantifier & OWA weights & ORness & Tradeoff & $\begin{array}{l}\text { GIS combination } \\
\text { procedure }\end{array}$ \\
& & & & & \\
\hline OR & $\alpha=0.0001$ & $1,0,0,0$ & 1.00 & 0.00 & OWA (max) \\
MIDOR & $\alpha=0.1$ & $0.89,0.03,0.05,0.04$ & 0.92 & 0.15 & OWA \\
AVG & $\alpha=0.5$ & $0.55,0.08,0.20,0.16$ & 0.67 & 0.59 & OWA \\
WLC & $\alpha=1$ & $0.3,0.1,0.3,0.3$ & 0.47 & 0.80 & OWA (WLC) \\
MIDAND & $\alpha=2$ & $0.09,0.07,0.33,0.51$ & 0.25 & 0.58 & OWA \\
AND & $\alpha=100$ & $0,0,0,1$ & 0.00 & 0.00 & OWA (min) \\
\hline
\end{tabular}

For the seaweed candidate $L$. digitata, the OWFs 4, 68, 69, 71 and 88 were assessed to be not or just partial suitable during the 3rd quarter and even more OWFs have been indexed as unsuitable during the 1st quarter. Next to variations with season the predicted suitability scores differed in comparison to the depth layers. $L$. digitata scored highest at a depth of 10-20 m (Figs. 5 and 6).

Assessing S. latissima resulted in suitable OWF sites during the 2nd and the 4th quarter at 0-10 $\mathrm{m}$ depth. L. hyperborea showed the most suitable sites in the 3rd quarter, a few during the 2nd and 4th quarter and none in the 1 st quarter. A depth of $10-20 \mathrm{~m}$ ensued higher suitability scores than 0 to $10 \mathrm{~m}$. For the seaweed candidate $P$. palmata, the 2nd quarter was assessed to be highly suitable, the 3rd and 4th quarter as partially suitable (Fig. 7). A significant difference between the depth levels for $P$. palmata could not be ascertained, whereas $D$. sanguinea only showed suitable sites at 10-20 m depth from the 2nd to the 4 th quarter (Fig. 6). Assessing the bivalve species during the 2 nd and 3rd quarter resulted in similar suitable sites for $O$. edulis and $C$. gigas, at both modelled depth levels (Fig. 6). The aquaculture candidate M. edulis only showed suitable sites at the OWFs 4, 68, 69, 71 and 88, all situated in front of the German coast, though at all depth levels assessed from the 2 nd to the 4th quarter. Another 'stable' candidate proved to be G. morhua at all depth levels and quarters, but especially showing high scores in between 30 to $40 \mathrm{~m}$ (Figs. 6 and 7). Assessing D. labrax resulted in a comparably low loss of suitable sites with the OWFs 4, 68, 69, 71 and 88 during the 1st quarter. The candidate scored highest at 10-20 m depth. While M. aeglefinus showed least suitable sites during the 2nd and 3rd quarter at all modelled depth levels (Fig. 7), S. maximus featured two suitable OWF sites (71 and 88) at 10$20 \mathrm{~m}$ depth and $20-30 \mathrm{~m}$ depth, both during the 3rd quarter. Assessing $H$. gammarus did not yield any suitable OWF.

In most of the cases the highest suitability scores were reached in the 2nd quarter (Fig. 6). Nevertheless, D. Labrax, S. maximus and L. hyperborea scored highest during the 3rd quarter. The differences between the quarters can be high, as for example for $M$. aeglefinus in the OWF areas 68 and 71, or comparatively low, as shown for $G$. morhua, where the suitability scores did not vary significantly with season (Fig. 7).
The suitability scores for selected OWF areas per quarter are shown at $0-10 \mathrm{~m}$ depth in Table 4 and at $10-20 \mathrm{~m}$ depth in Table 5. Several OWFs provided robust sites suitable for multiple aquacultures such as 69 or 88, exhibiting a possible combination of six or ten aquaculture candidates, respectively. Table 4 enables the decision maker to choose from a set of candidates and between the most suitable sites for M. edulis, O. edulis, C. gigas, L. hyperborea, P. palmata, L. digitata, D. sanguinea or S. latissima.

Table 5 features a selection of suitability scores for G. morhua, D. Labrax, M. aeglefinus, S. maximus, M. edulis, O. edulis, C. gigas, $L$. hyperborea, P. palmata, L. digitata, D. sanguinea and S. latissima. The OWF areas shown in Table 5 exhibited comparably high suitability scores for M. aeglefinus, (6-9), O. edulis, (7-9) and L. digitata (6-8).

\section{Discussion}

Competition for maritime space has highlighted the need for efficient management and synergies between different activities. Within the scope of the project OSS, sites suitable for co-location of individual offshore aquacultures in combination with OWFs were indexed. In the present publication the applicability of the GIS-MCE to assess the suitability of such sites is demonstrated.

\subsection{The weighted GIS-based modelling framework}

Uncertainty in standardised data derived by expert knowledge and uncertainty from the interaction of ranked criteria can be smoothed out using the fuzzy membership functions. These functions have already been successfully applied in a range of analyses using MCE [30,32,33]. Nevertheless, in the course of this study, using the AHP resulted in inconsistent judgments $(C R<0.1)$ for the three bivalve species blue mussel $M$. edulis, European oyster $O$. edulis and Pacific oyster $C$. gigas. This inconsistency might be explained by a high preference only given to chlorophyll a (0.34). These original weights need to be revised in the future.

Employing the OWA technique resulted in a range of aggregation methods to combine factor attributes determining the suitability of aquaculture sites. Applying the OR operator revealed a high risk (ORness) to overestimate the factor with the highest corresponding value. Hence, the OR scenario might be interpreted as the most optimistic and risky evaluation strategy. Consequently, the OR operator is not applicable for the determination of suitable aquaculture sites. The risk of ignoring essential factors is just too high. On the contrary, applying the AND operator yielded a low risk in overestimating factors as it is based on the lowest factor value. Therefore, it can be interpreted as the most conservative and risk averse evaluation strategy and is regarded as applicable for the determination of suitable aquaculture sites. Applying the WLC or other operators between OR and AND resulted in intermediate risk levels for the aquaculture candidates. The lowest risk level (turbot $S$. 

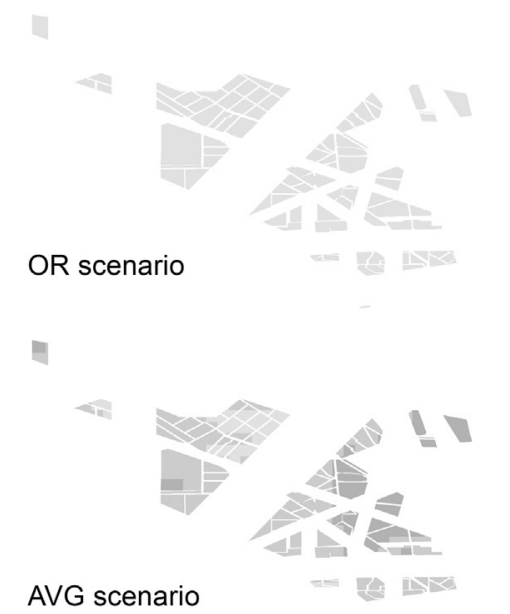

$$
\text { (1 }
$$

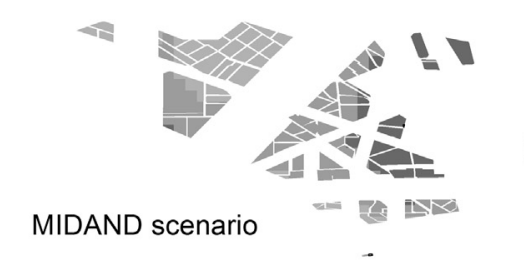

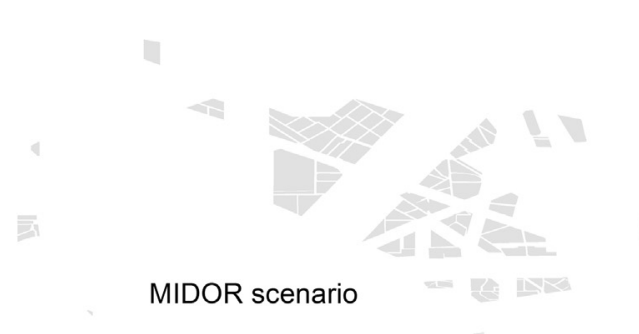

$+$
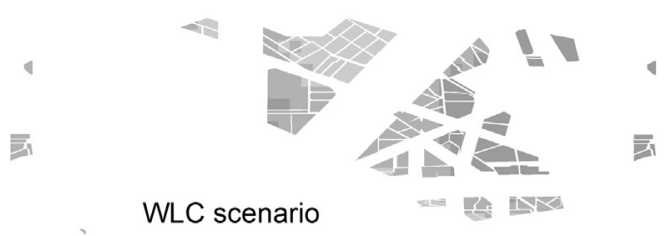

(1)

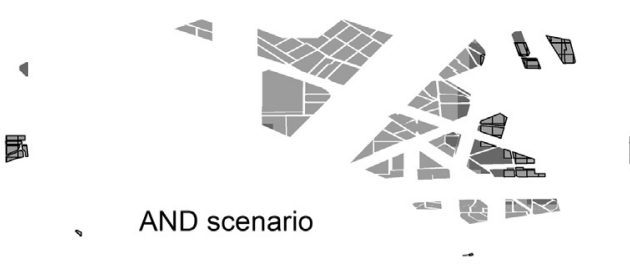

$\theta$

㞗

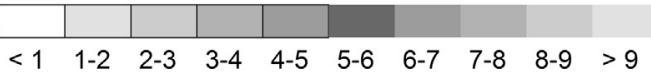

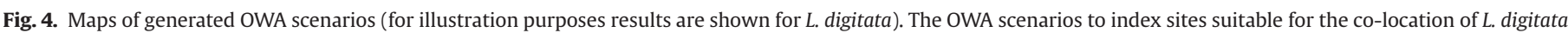

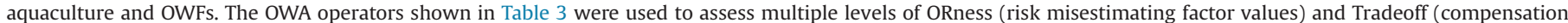

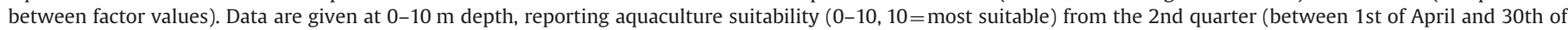
June) in the German EEZ of the North Sea.

maximus) was given when applying the WLC operator and can be explained by the fact, that high factor values were combined with low order weights and vice versa.

As the degree of compensation (Tradeoff) depends on the weights distributed across all factors included into a weighting combination, both, the OR and the AND scenario resulted in a Tradeoff of 0 . Whereas the WLC scenario yielded multiple degrees of compensation, individually depending on the factor weights distributed when evaluating each candidate. Full compensation (in combination with a low risk level) was reached when all factors were weighted equally as for dulse P. palmata and cuvie L. hyperborea in the WLC scenario assessment. In summary, all modelled outputs were consistent and demonstrated overlaps among the scenarios for individual aquaculture candidates. Moreover, results from the AND scenario yielded usually the same aquaculture candidates as most suitable as revealed with the WLC scenario.

\subsection{Suitability for co-location of offshore aquaculture and wind farms}

Considering both, the AND scenario and the WLC scenario during risk analysis was justified by the following facts:

The weighting of the factors was judged by experts. In reality, from a biological perspective, factors such as highly preferred temperature cannot compensate unsuitable oxygen concentrations. All factors determine the suitability of an area. Moreover, interpreting these results from an economic point of view, the AND scenario was the most certain approach as the factor limiting the suitability was weighted discretely. Therefore, a complete failure leading to the loss of organisms and in this way to the loss of aquaculture revenues can be classified as improbable. Furthermore, when using the AND scenario, expert judgement in weighting the factors determining aquaculture suitability is treated with caution because it can be incomplete, affected by natural randomness or imprecise due to vague, underspecified or context-dependent terms [57].

However, the focus of this study has been on defining areas for the co-location of OWF areas and offshore aquacultures. When providing basic management scenarios for decision makers, there is a principal need to include cost effective settings. Therefore, the factors were weighted according to optimal growth under farmed conditions by expert judgment. The WLC scenario resulted in the same weighting scheme as given by expert opinion and can therefore be interpreted as the most cost effective one. Even so, using the WLC, the highest degrees of compensation were reached and the level of risk estimating the factor attributes varied disproportionately.

Apart from this, all following results discussed below were based on the offshore co-location suitability index, which was developed by accounting for (i) overlaps between the aquaculture sites and the OWF areas and (ii) distance of the OWF to the next harbour.

\subsubsection{Fish}

European sea bass (D. labrax) showed high suitability in combination with OWF areas over all depth layers and quarters. Analysing this candidate during the 2nd quarter at the OWF areas 4, 54, 55, 69 and 88 , which are all situated near the transition zone from offshore to nearshore (12 $\mathrm{nm}$ boarder) at 10-20 m depth, resulted in low interquartile ranges (IQR). Therefore, the results depict a similar suitability in all seasons. Even higher suitability scores were yielded for Atlantic cod (G. morhua). This agrees with [44], 
AND scenario

由

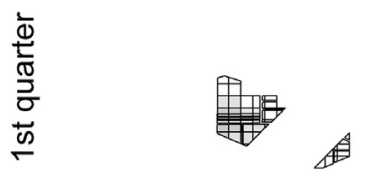

$+$

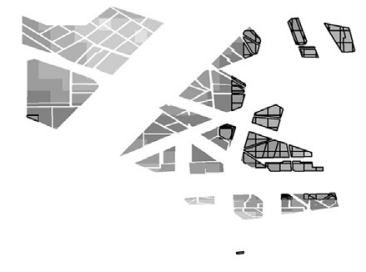

B
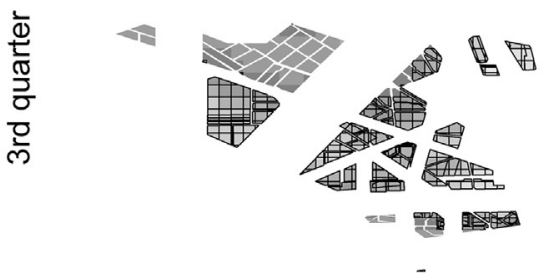

日
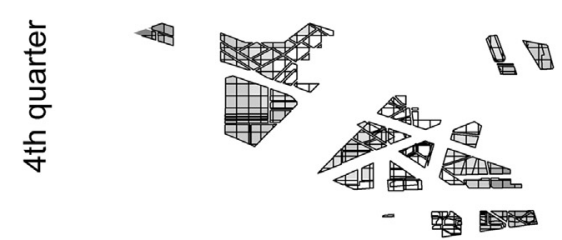
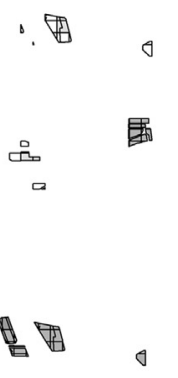

尿

日

WLC scenario

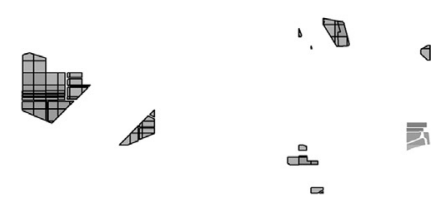

(1)

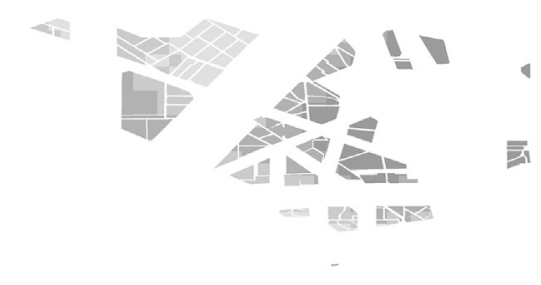

口

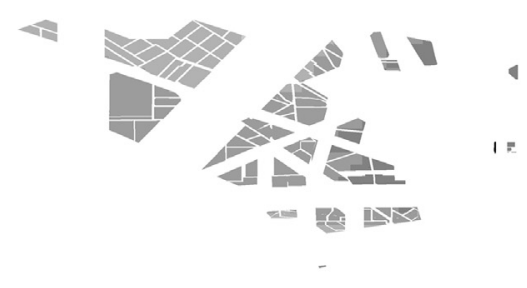

Q

$\theta$

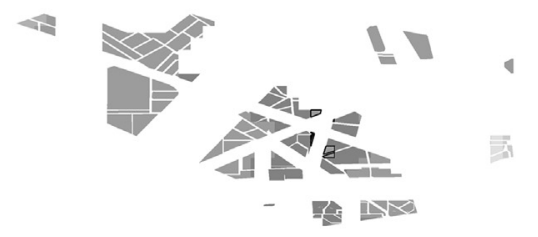

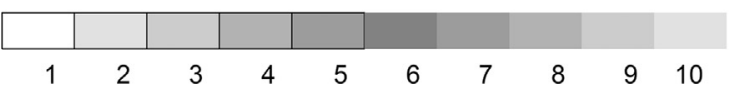

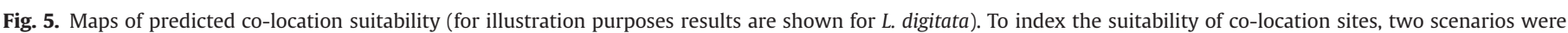

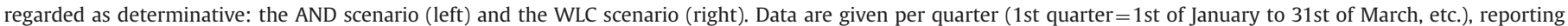
aquaculture suitability $(0-10,10=$ most suitable) for $L$. digitata at a depth of $10-20 \mathrm{~m}$ in combination with OWF areas in the German EEZ of the North Sea.

who showed that cultivating cod all year-round (1.5 years) submerged $12 \mathrm{~m}$ below the surface resulted in a survival rate of $92 \%$. The same cultivation approach was tested successfully for haddock (M. aeglefinus). Within this study, the high IQR given in Table 5 disagree with these results, which can also be said about the best suitability scores yielded at 20-30 m depth (Fig. 7). The most efficient scenario shown for haddock scored the highest suitability in the 2nd quarter where ammonium was not considered. Ammonium usually limits the suitability for fish species cultivated in onshore recirculation aquaculture systems due to toxic effects of ammonia in high concentrations. Nevertheless, these concentrations get resolved in offshore areas by strong currents, moreover benefitting from strong wave action and harsh offshore winds. Therefore, recirculation aquaculture system conditions are hard to compare to offshore conditions. Furthermore, the results out of the 3rd quarter showed comparably high scores for haddock. The low values for turbot can be explained by the parameterisations chosen during standardisation procedure. Limitations were given due to the parameterisation of temperature and the rather low current velocity turbot (S. maximus) can withstand.

\subsubsection{Crustaceans}

Analysing European lobster ( $H$. gammarus) did not result in any suitable aquaculture site at all. The factor reducing the suitability was identified to be current velocity, which has been defined as unsuitable $>0.25 \mathrm{~m} / \mathrm{s}$.

\subsubsection{Bivalves}

The suitability scores for blue mussels (M. edulis) at 0 to $10 \mathrm{~m}$ depth (Fig. 7) are confirmed by a study of $[58,22]$, who demonstrated a 7 to 18 times higher biomass for blue mussels located higher up in the water column (on collectors or artificial reefs, such as turbine pillars) than those located deeper (on the scour protection), caused by an enhanced advective food supply. It has to be noted for this type of cultivation, that mussels have two cultivation stages, (1) collecting the seed and (2) grow out to market size. The latter stage is the important one in the context of this study.

In general, offshore mussel cultures might be feasible as indicated by the high suitability scores Pacific oyster ( $C$. gigas) and European oyster (O. edulis) yielded at the OWF areas 5 or 70. 

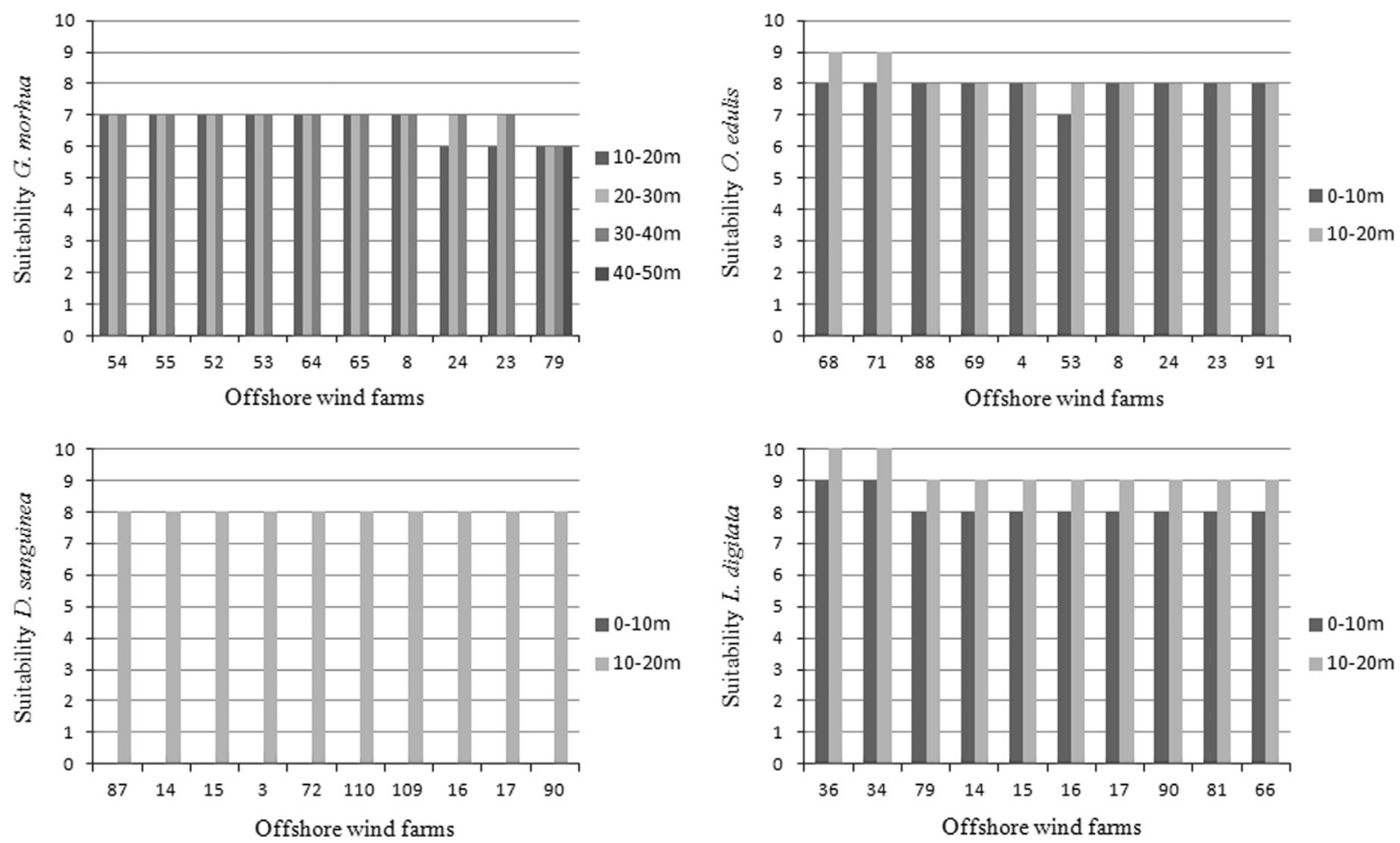

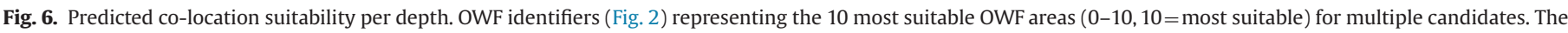

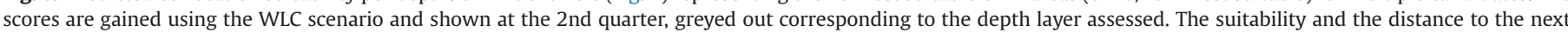
harbour determined the order of the OWF identifiers*.

*Note: wave height was not considered below $10 \mathrm{~m}$, ammonium was not considered assessing G. morhua
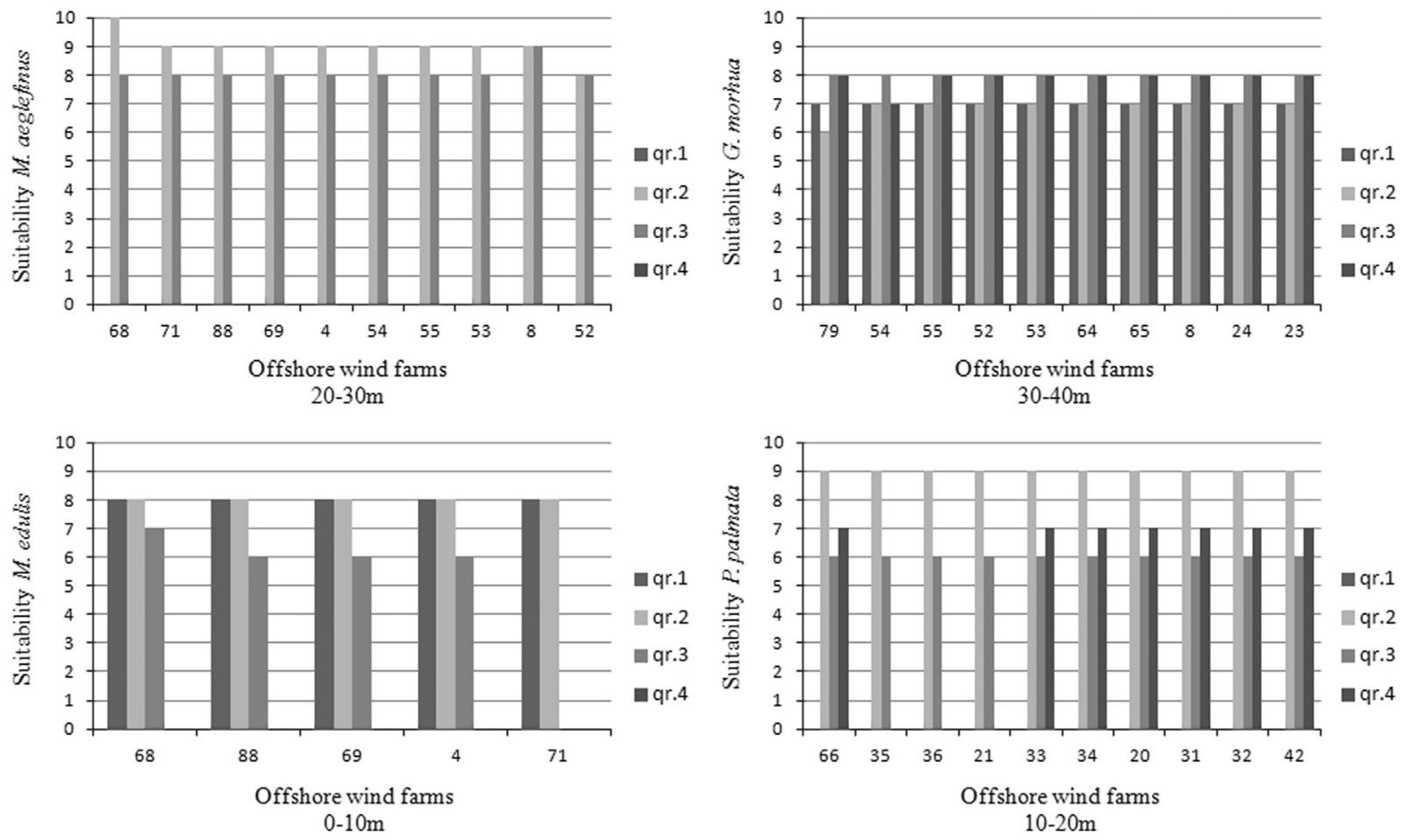

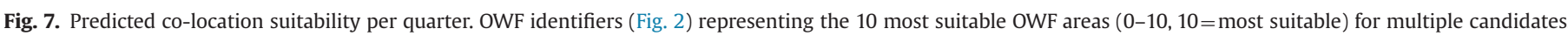

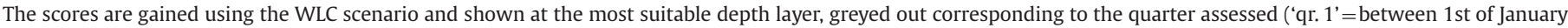
and 31th of March etc.). The suitability and the distance to the next harbour determined the order of the OWF identifiers*.

*Note: wave height was not considered below $10 \mathrm{~m}$, ammonium was not considered in the 2 nd quarter for M. aeglefinus.

These ones are stable over the year within both modelled depth layers (Tables 4 and 5, Fig. 6). There are already nearshore mussel cultures in the Wadden Sea of the German EEZ, in nearshore waters of Ireland and Scotland and in offshore waters of the USA, France, the Netherlands, New Zealand, Japan, and China [19]. 
Table 4

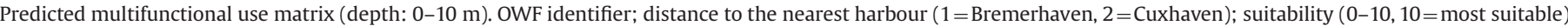

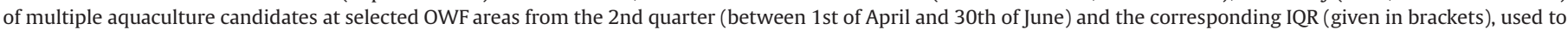

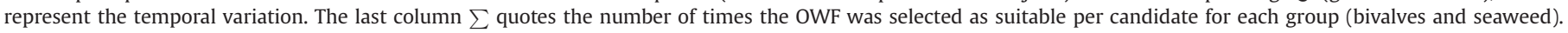

\begin{tabular}{|c|c|c|c|c|c|c|c|c|c|c|c|c|}
\hline OWF & Distance & Harbour & C. gigas & O. edulis & M. edulis & $\sum$ & L. hyperborea & L. digitata & P. palmata & S. latissima & D. sanguinea & $\sum$ \\
\hline 88 & 91.54 & 2 & $8(8)$ & $8(6.5)$ & $8(3.5)$ & 3 & $0(6)$ & $6(0.75)$ & $4(3.25)$ & $8(2)$ & $0(0)$ & 3 \\
\hline 69 & 94.18 & 2 & $9(8.25)$ & $8(7.25)$ & $8(2.75)$ & 3 & $0(6)$ & $6(0.75)$ & $4(3)$ & $8(2)$ & $0(0)$ & 3 \\
\hline 54 & 110.9 & 1 & $7(5.5)$ & $7(5.5)$ & $0(0)$ & 2 & $6(6)$ & $7(0.5)$ & $6(2.25)$ & $9(3.75)$ & $0(0)$ & 4 \\
\hline 55 & 113.1 & 1 & $7(5.5)$ & $7(5.5)$ & $0(0)$ & 2 & $6(6)$ & 7 (1.75) & $6(1.5)$ & $9(3.75)$ & $0(0)$ & 4 \\
\hline 53 & 117.4 & 1 & $7(5.5)$ & $7(5.5)$ & $0(0)$ & 2 & $6(6)$ & $8(2)$ & $6(1.5)$ & $9(2.25)$ & $0(0)$ & 4 \\
\hline 72 & 144.4 & 1 & $8(8)$ & $8(6.5)$ & $8(8)$ & 3 & $0(1.5)$ & $6(2)$ & $4(4.75)$ & $8(2)$ & $0(0)$ & 3 \\
\hline 5 & 188.9 & 1 & $8(8)$ & $8(6.5)$ & $8(3.5)$ & 3 & $0(6)$ & $6(0.75)$ & $4(3.25)$ & $8(2)$ & $0(0)$ & 3 \\
\hline 70 & 197.1 & 1 & $8(8)$ & $8(6.5)$ & $8(3.5)$ & 3 & $0(6)$ & $6(0.75)$ & $4(3.25)$ & $8(2)$ & $0(0)$ & 3 \\
\hline 19 & 200.3 & 1 & $8(8)$ & $8(7.25)$ & $8(7.25)$ & 3 & $0(4.5)$ & $6(0.75)$ & $4(2)$ & $8(2)$ & $0(0)$ & 3 \\
\hline 11 & 201.1 & 1 & $6(5.25)$ & $6(6)$ & $0(0)$ & 2 & $6(6)$ & $8(2)$ & $7(2.5)$ & $8(5.75)$ & $0(0)$ & 4 \\
\hline
\end{tabular}

Table 5

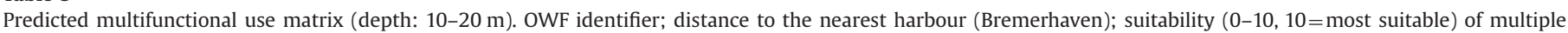

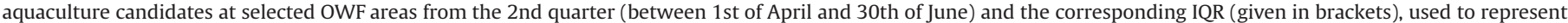
the temporal variation. The last column $\sum$ quotes the number of times the OWF was selected as suitable per candidate for each group (fish, bivalves and seaweed).

\begin{tabular}{|c|c|c|c|c|c|c|c|c|c|c|c|c|c|c|c|c|c|}
\hline OWF & Distance & Harbour & $\begin{array}{l}\text { D. } \\
\text { labrax }\end{array}$ & $\begin{array}{l}S . \\
\text { maximus }\end{array}$ & $\begin{array}{l}\text { M. } \\
\text { aeglefinus }\end{array}$ & $\begin{array}{l}\text { G. } \\
\text { morhua }\end{array}$ & $\sum$ & C. gigas & $\begin{array}{l}\text { O. } \\
\text { edulis }\end{array}$ & $\begin{array}{l}\text { M. } \\
\text { edulis }\end{array}$ & $\sum$ & $\begin{array}{l}\text { L. } \\
\text { hyperborea }\end{array}$ & $\begin{array}{l}\text { L. } \\
\text { digitata }\end{array}$ & $\begin{array}{l}P . \\
\text { palmata }\end{array}$ & $\begin{array}{l}\text { S. } \\
\text { latissima }\end{array}$ & $\begin{array}{l}D . \\
\text { sanguinea }\end{array}$ & $\sum$ \\
\hline 88 & 91.54 & 2 & $5(2.75)$ & $0(1.5)$ & $9(8.25)$ & $7(1)$ & 3 & $8(8)$ & $8(6.5)$ & $8(2.75)$ & 3 & $0(6)$ & $6(1)$ & $5(4.25)$ & $7(1.75)$ & $6(0.75)$ & 4 \\
\hline 69 & 94.18 & 2 & $5(2.75)$ & $0(0)$ & $8(8)$ & $7(1)$ & 3 & $9(8.25)$ & $9(6.75)$ & $8(2.75)$ & 3 & $0(6)$ & $6(1)$ & $5(4)$ & $6(2.5)$ & $6(0.75)$ & 4 \\
\hline 54 & 110.9 & 1 & $6(1.5)$ & $0(0)$ & $9(8.25)$ & $7(1)$ & 3 & $7(5.5)$ & $8(5)$ & $0(0)$ & 2 & $6(6.25)$ & $8(1)$ & $7(2.5)$ & $7(7)$ & $7(0.75)$ & 5 \\
\hline 55 & 113.1 & 1 & $5(0.75)$ & $0(0)$ & $9(8.25)$ & $7(1)$ & 3 & $7(5.5)$ & $7(4.75)$ & $0(0)$ & 2 & $6(6.25)$ & $8(2)$ & $7(2.5)$ & $8(7.25)$ & $7(1.75)$ & 5 \\
\hline 53 & 117.4 & 1 & $5(0.75)$ & $0(0)$ & $9(9)$ & $7(1)$ & 3 & $7(5.5)$ & $7(4.75)$ & $0(0)$ & 2 & $6(6.25)$ & $8(2)$ & $7(2.5)$ & $7(6.25)$ & $7(1.75)$ & 5 \\
\hline 65 & 124 & 1 & $5(0.75)$ & $0(0)$ & $8(8.25)$ & $7(1)$ & 3 & $7(5.5)$ & $7(4.75)$ & $0(0)$ & 2 & $5(5.5)$ & $8(2)$ & $7(2.5)$ & $7(6.25)$ & $7(1.75)$ & 5 \\
\hline 91 & 139.4 & 1 & $5(0.75)$ & $0(0)$ & $8(8.25)$ & $7(0.25)$ & 3 & $7(6.25)$ & $8(5)$ & $0(0)$ & 2 & $5(5.25)$ & $7(1.5)$ & $6(3)$ & $7(2.5)$ & $6(1.25)$ & 5 \\
\hline 5 & 188.9 & 1 & $5(0.75)$ & $0(0)$ & $6(6.5)$ & $6(0.5)$ & 3 & $8(8)$ & $8(6.5)$ & $8(2.75)$ & 3 & $0(6)$ & $6(1)$ & $5(4.25)$ & $7(1.75)$ & $6(0.75)$ & 4 \\
\hline 70 & 197.1 & 1 & $5(0.75)$ & $0(0)$ & $7(8)$ & $6(0.5)$ & 3 & $8(8)$ & $8(6.5)$ & $8(2.75)$ & 3 & $0(6)$ & $6(1)$ & $5(4.25)$ & $7(1.75)$ & $6(0.75)$ & 4 \\
\hline 9 & 208.5 & 1 & $5(1.25)$ & $0(0)$ & $6(6.5)$ & $6(0.5)$ & 3 & $7(6.25)$ & $8(5.75)$ & $0(0)$ & 2 & $5(5.25)$ & $7(2.25)$ & $7(3.25)$ & 7 (1.75) & $7(1.5)$ & 5 \\
\hline
\end{tabular}

\subsubsection{Seaweed}

According to [19], the seaweed candidates of the genus Laminaria (L. digitata, S. latissima and L. hyperborea) prefer low water temperatures. Indeed, $L$. hyperborea showed higher values at 10-20 m depth but scored highest in the 3rd quarter, while the lowest temperature occurs during the 4th and 1st quarter. At this point, it has to be taken into account that seaweed cultivation strongly depends on the season. If the seaweed is part of an IMTA approach and also a candidate to be sold on the EU market, it has to be harvested latest by the end of the 2nd quarter. If the seaweed is cultivated within a bioremediation concept and is only used to extract nutrients from the water column, it can be on-site year around [59].

The whole study area became only suitable for $D$. sanguine in deeper waters. This can be explained by the fact, that wave height, which limits the suitability for seaweed species, becomes a minor impact at depths below $10 \mathrm{~m}$. Furthermore, according to [19], seaweed offshore cultures are adaptable to limited light conditions and can therefore be cultivated at greater depth. Moreover, if seeded elaborately on the rope and transferred at sea at a juvenile stage, holdfasts will not be dislodged and cauloids will not break leading to a resistance to harsh conditions [53]. These might be interesting facts for culturing the seaweeds P. palmata, L. digitata, $D$. sanguine and L. hyperborea, as these candidates scored highest at 10 to $20 \mathrm{~m}$ depth.

During a study by [60], S. latissima was cultivated in the most effective way at a depth of 2 and $5 \mathrm{~m}$ during early summer time. These results match the suitability scores attained during the 2nd quarter at 0-10 $\mathrm{m}$ depth (Table 4). Judged by the fact, that S. latissima has a preference to take up ammonium, the factor was included in the determination of suitable sites (Table 1). The high scores could therefore be explained by the fact, that there was no ammonium considered in the 2nd quarter. However, as ammonium has been weighted with 0.01 during the AHP, this fact might be disregarded.
The range of suitability scores for identified aquaculture candidates across the OWF areas per quarter reflected the dependence of each candidate on local conditions in the study area and key environmental criteria as given in Table 1. Furthermore, the differences in the suitability between depth layers and quarters justified the scenario settings as described in Section 2.2. Consequently, if strong currents and waves limit the suitability over the year, affected candidates might be initially cultivated onshore and subsequently applied offshore at a more resilient stage. This might be possible for fish and oyster species showing high suitability in certain quarters but also high IQRs, such as at the OWF areas 88 and 69 (Table 5). When evaluating the OWFs 34 and 36 (Fig. 6), a kind of patchiness gets visible, as these OWFs are situated next to each other further offshore, where the temperature is lower than nearshore. The OWF areas 4, 68, 69 and 71 and 88 are situated near the transition zone from offshore to nearshore $(12 \mathrm{~nm}$ boarder) at a depth of $10-20 \mathrm{~m}$, exhibiting higher temperatures as well as nutrient enriched water columns.

With the focus on IMTA, the results given in Tables 4 and 5 are quite revealing: The suitability scores given at the OWF areas situated near the $12 \mathrm{~nm}$ boarder (54, 55, 69 and 88; depth: 10-20 $\mathrm{m}$ ) indicate a possible set of aquaculture candidates consisting of $M$. aeglefinus, $O$. edulis and $L$. digitata, favourable for IMTA techniques at least in one quarter. These results might be explained by nutrient rich water layers due to river inflows.

IMTA techniques bring along a number of advantages such as better growth rates of Laminaria species cultured near fish farms $[60,61]$. Nevertheless, seaweed cultures need a large space at the ocean's surface, whereas mussels have to be cultured in high numbers if they shall function as biofilters to remediate particles out of the water column [19] and to ensure environmental balance or economic benefits. Limitations might be possible regarding aquaculture technologies such as IMTA constructions or alterations needed concerning the OWF structures. Within this study, as 
described in Section 2.4, all OWF areas have been included, even those already at work. Furthermore, we included all depth levels given in Table 1, although the cultivation at different water depths will require different technologies, some of them more feasible than others. Information about offshore installations, alterations required or other further details might be provided by $[62,53,13,19]$.

The potential of a site for co-location depends on biological, ecological and hydrological factors. Furthermore, commercial, legal and social factors have to be addressed [3]. The present GIS-MCE modelling approach is a first step to analyse potential synergies within the German EEZ of the North Sea. Subsequent steps need to comprise (1) an analysis of profitability on coupling offshore IMTA candidates, (2) the assessment of the environmental carrying capacity, (3) an environmental impact assessment, (4) the analysis of the economic viability of co-locations, (5) the analysis of co-management strategies (e.g. [11]) and (6) an integrated assessment process of the German MSP concerning measures to grant facilities for volunteering co-location (OWF and IMTA) developers in comparison to mono-use OWF developers.

Following the biological site-selection presented in this paper, next steps comprise the analysis of the economic viability and the analysis on the integration of the co-location concept in existing maritime spatial planning processes.

\section{Conclusion}

The resulting suitability scores reveal several possible sets of seaweed, bivalves and fish candidates, favourable for IMTA techniques at least in one quarter. The present results illustrate how competing needs might be balanced in planning for both offshore wind energy and offshore IMTA in the German EEZ of the North Sea.

In conclusion, the GIS-based framework is a suitable tool to analyse synergies regarding space issues among user groups, to offer guidance to stakeholders and assist decision-makers in determining the most suitable sites for pilot projects using IMTA techniques. The co-location of OWFs in combination with offshore IMTA systems might be seen as a milestone towards sustainable MSP, ensuring the continuity of aquatic resources for future generations, however, final decisions still need to be made by decision makers.

\section{Acknowledgements}

The German Federal Office for Agriculture and Food (Bundesanstalt für Landwirtschaft und Ernährung, BLE) funded this study, which is a part of the project Offshore Site Selection (OSS) (31306.01-28-1-73.010-10). The data were freely provided by National Oceanographic and Atmospheric Administration (NOAA), HelmholtzZentrum Geesthacht - Centre for Materials and Coastal Research (HZG) and the German Federal Maritime and Hydrographic Agency (Bundesamt für Seeschifffahrt und Hydrographie, BSH), Hamburg (Germany) in raw, uninterpreted form.

\section{References}

[1] Godfray HC, Beddington JR, Crute IR, Haddad L, Lawrence D, Muir JF, et al. Food security: the challenge of feeding 9 billion people. Science 2010;327:812-8.

[2] FAO. Food and agriculture organization of the united nations. Rome: The State of World Fisheries and Aquaculture; 2014 (223 p.).

[3] Christie N, Smyth K, Barnes R, Elliott M. Co-location of activities and designations: A means of solving or creating problems in marine spatial planning? Mar Policy 2014;43:254-63.

[4] Gimpel A, Stelzenmüller V, Cormier R, Floeter J, Temming A. A spatially explicit risk approach to support marine spatial planning in the German EEZ. Mar Environ Res 2013;86:56-69.
[5] Stelzenmüller V, Schulze T, Gimpel A, Bartelings H, Bello E, Bergh O, et al. Guidance on a better integration of aquaculture, fisheries, and other activities in the coastal zone: from tools to practical examples. COEXIST project; 2013. $79 \mathrm{p}$.

[6] Soma K, Ramos J, Bergh O, Schulze T, van Oostenbrugge H, van Duijn AP, et al The mapping out approach: effectiveness of marine spatial management options in European coastal waters. ICES J Mar Sci 2013;71:2630-42.

[7] Rosenthal H, Costa-Pierce B, Krause G, Buck BH. Bremerhaven declaration on the future of global open ocean aquaculture - Part II: recommendations on subject areas and justifications. Aquaculture forum on open ocean aquaculture development - from visions to reality: the future of offshore farming funded by: investment in sustainable fisheries co-financed by the European Union (European Fisheries Fund - EFF), Ministry of Economics, Labour and Ports (Free Hanseatic City of Bremen), The Bremerhaven Economic Development Company Ltd.; 2012. p. 8.

[8] EC (European Commission). Maritime affairs policy blue growth. 〈http://ec europa.eu/maritimeaffairs/policy/blue growth/ $; 2014$.

[9] EC (European Commission). Environment marine directive good environmental status. 〈http://ec.europa.eu/environment/marine/good-environmental-sta tus/index_en.htm>; 2014.

[10] Grote B, Buck BH. The IMTA-approach for nutrient balanced aquaculture: evaluating the potential of North Sea species from onshore RAS to offshore environments. Aquaculture 2015 (in preparation).

[11] Buck BH, Krause G, Rosenthal H. Extensive open ocean aquaculture development within wind farms in Germany: the prospect of offshore co-management and legal constraints. Ocean Coast Manag 2004;47:95-122.

[12] Kaiser MJ, Yu Y, Snyder B. Economic feasibility of using offshore oil and gas structures in the Gulf of Mexico for platform-based aquaculture. Mar Policy 2010;34:699-707.

[13] Benassai G, Mariani P, Stenberg C, Christoffersen M. A Sustainability Index of potential co-location of offshore wind farms and open water aquaculture. Ocean Coast Manag 2014;95:213-8.

[14] Buck BH, Krause G. Integration of Aquaculture and Renewable Energy Systems Encycl Sustain Sci Technol 2012;1:511-33.

[15] Wever L, Krause G, Buck BH. Lessons from stakeholder dialogues on marine aquaculture in offshore wind farms: perceived potentials, constraints and research gaps. Mar Policy 2015;51:251-9.

[16] Buck BH, Krause G. Short Expertise on the Potential Combination of Aquaculture with Marine-Based Renewable Energy Systems. SeaKult-Sustainable Futures in the Marine Realm. Expertise für das WBGU-Hauptgutachten „Welt im Wandel: Menschheitserbe Meer“. Wissenschaftlicher Beirat der Bundesregierung Globale Umweltveränderungen (WBGU); 2013 (58 p.).

[17] Neori A, Troell M, Chopin T, Yarish C, Critchley A, Buschmann AH. The need for a balanced ecosystem approach to blue revolution aquaculture. Environment 2007;49:37 (Research Library Core).

[18] Troell M., Chopin T., Angel D., Buck B.H. IMTA and offshore aquaculture development.Aquac Eng. in preparation.

[19] Troell M, Joyce A, Chopin T, Neori A, Buschmann AH, Fang J-G. Ecological engineering in aquaculture - potential for integrated multi-trophic aquaculture (IMTA) in marine offshore systems. Aquaculture 2009;297:1-9.

[20] Barrington K, Ridler N, Chopin T, Robinson S, Robinson B. Social aspects of the sustainability of integrated multi-trophic aquaculture. Aquac Int 2008;18:201-11.

[21] Benassai G, Stenberg C, Christoffersen M, Mariani P. A sustainability index for offshore wind farms and open water aquaculture. In: Proceedings of the second international conference on physical coastal processes, management and engineering, Naples, Italy, 27-29 April 2011; 2011.

[22] Buck BH. Experimental trials on the feasibility of offshore seed production of the mussel Mytilus edulis in the German Bight: installation, technical requirements and environmental conditions. Helgol Mar Res 2007;61:87-101.

[23] UNH (University of New Hampshire). Atlantic marine aquaculture center 〈http://ooa.unh.edu/publications/publications_briefs.html〉; 2014.

[24] Pogoda B, Buck BH, Hagen W. Growth performance and condition of oysters (Crassostrea gigas and Ostrea edulis) farmed in an offshore environment (North Sea, Germany). Aquaculture 2011;319:484-92.

[25] Joschko TJ, Buck BH, Gutow L, Schröder A. Colonization of an artificial hard substrate by Mytilus edulis in the German Bight. Mar Biol Res 2008;4:350-60.

[26] Michler-Cieluch T, Krause G, Buck BH. Reflections on integrating operation and maintenance activities of offshore wind farms and mariculture. Ocean Coast Manag 2009;52:57-68.

[27] Buck BH, Krause G, Michler-Cieluch T, Brenner M, Buchholz CM, Busch JA, et al. Meeting the quest for spatial efficiency: progress and prospects of extensive aquaculture within offshore wind farms. Helgol Mar Res 2008;62:269-81.

[28] ElMahdi A, Kheireldin K. GIS and mulit-criteria evaluation for integrated wate resources. conserving soil and water for society: sharing solutions. Brisbane, July 2004, Paper No. 1014; 2004. p. 1-7.

[29] Al-Yahyai S, Charabi Y, Gastli A, Al-Badi A. Wind farm land suitability indexing using multi-criteria analysis. Renew Energy 2012:44:80-7.

[30] Gorsevski PV, Donevska KR, Mitrovski CD, Frizado JP. Integrating multi-criteria evaluation techniques with geographic information systems for landfill site selection: a case study using ordered weighted average. Waste Manag 2012:32:287-96.

[31] Perez OM, Telfer TC, Ross LG. Geographical information systems-based models for offshore floating marine fish cage aquaculture site selection in Tenerife, Canary Islands. Aquac Res 2005:36:946-61.

[32] Malczewski J. Ordered weighted averaging with fuzzy quantifiers: GIS-based multicriteria evaluation for land-use suitability analysis. Inte J Appl Earth Obs Geoinf 2006;8:270-7. 
[33] Boroushaki S, Malczewski J. Implementing an extension of the analytical hierarchy process using ordered weighted averaging operators with fuzzy quantifiers in ArcGIS. Comput Geosci 2008;34:399-410.

[34] Ouma Y, Tateishi R. Urban flood vulnerability and risk mapping using integrated multi-parametric AHP and GIS: methodological overview and case study assessment. Water 2014;6:1515-45.

[35] BSH. The Federal Agency for shipping and hydrography (Bundesamt für Seeschifffahrt und Hydrographie, BSH). Map North Sea. 〈http://www.bsh.de/ en/Marine_uses/Spatial_Planning_in_the_German_EEZ/documents2/MSP_DE_ NorthSea.pdf $; 2009$.

[36] Fock HO. Natura 2000 and the European Common Fisheries Policy. Mar Policy 2011;35:181-8.

[37] Stelzenmüller V, Schulze T, Fock HO, Berkenhagen J. Integrated modelling tools to support risk-based decision-making in marine spatial management. Mar Ecol Prog Ser 2011;441:197-212.

[38] Weisse R, Plü $\beta$ A. Storm-related sea level variations along the North Sea coast as simulated by a high-resolution model 1958-2002. Ocean Dyn 2005;56:16-25.

[39] Eastman JR. Guide to GIS and Image Processing. Idrisi Prod 2001;2:1-141.

[40] FAO (Food and Agriculture Organization of the United Nations). Fisheries and Aquaculture Department Cultured Aquatic Species Information Programme (CASIP) Dicentrarchus labrax. 〈http://www.fao.org/fishery/species/2291/en〉; 2014.

[41] Moksness E, Kjorsvik E, Olsen Y. Culture of cold-water marine fish. WileyBlackwell; 2004 (544 p.).

[42] Person-Le Ruyet J, Buchet V, Vincent B, Le Delliou H, Quéméner L. Effects of temperature on the growth of pollack (Pollachius pollachius) juveniles. Aquaculture 2006;251:340-5.

[43] Daniels HV, Watanabe WO. Practical flatfish culture and stock enhancement. Wiley Blackwell; 2010 (392 p.).

[44] Chambers M, Howell W. Preliminary information on cod and haddock production in submerged cages off the coast of New Hampshire, USA. ICES J Mar Sci 2006;63:385-92.

[45] Jobling M. A review of the physiological and nutritional energetics of cod, Gadus morhua L., with particular reference to growth under farmed conditions. Aquaculture 1988;70:1-19.

[46] Rosenberg R, Hellmann B, Johannson B. Hypoxic tolerance of marine benthic fauna. Mar Ecol Prog Ser 1991;79:127-31.

[47] MarLIN (Marine Life Information Network). 〈http://wwwmarlinacuk/searchin dexphp?searchType=speciesspeciesSearch $\rangle ; 2014$; [retrieved: April 17th].

[48] Cano J, Rosique J, Rocamora J. Influence of environmental parameters on reproduction of the European flat oyster (Ostrea edulis L.) in a coastal lagoon (Mar Menor, Southeastern Spain). J. Molluscan Stud 1997;63:187-96.
[49] Karayücel S, Karayücel I. The effect of environmental factors, depth and position on the growth and mortality of raft-cultured blue mussels (Mytilus edulis L.). Aquac Res 2000;31:893-9.

[50] Mc Hugh D.J. A guide to the seaweed industry. FAO fisheries technical paper; 2003. p. 441

[51] Bolton J, Lüning K. Optimal growth and maximal survival temperatures of Atlantic Laminaria Species (Phaeophyta) in culture. Mar Biol 1982:66.

[52] Lüning K. Seaweeds - their environment, biogeography, and ecophysiology. Wiley; 1990 (544 p.).

[53] Buck BH, Buchholz CM. The offshore-ring: a new system design for the open ocean aquaculture of macroalgae. J. Applied Phycol 2004;16:355-68.

[54] Werner A, Dring M. Aquaculture explained No. 27: cultivating Palmaria palmata. Irish Sea Fisheries Board; 2011.

[55] Jiang H, Eastman JR. Application of fuzzy measures in multi-criteria evaluation in GIS. Int J Geogr Inf Sci 2000;14:173-84.

[56] BfN.Natura 2000 Marine Protected Areas in the EEZ. 2014. Federal Agency for Nature Conservation (Bundesamt für Naturschutz); 〈http://www.bfn.de/0314 meeresschutzgebiete.html ; 2008.

[57] Perera AH, Drew CA, Johnson CJ. Expert knowledge and its application in landscape ecology. Springer Science \& Business Media; 2011 (322 p.).

[58] Maar M, Bolding K, Petersen JK, Hansen JLS, Timmermann K. Local effects of blue mussels around turbine foundations in an ecosystem model of Nysted off-shore wind farm, Denmark. J Sea Res 2009;62:159-74.

[59] Buchholz CM, Krause G, Buck BH. Seaweed and Men. In: Wiencke C, Bischof K, editors. Seaweed Ecophysiology \& Ecology. Ecological Studies of Springer; 2012.

[60] Handå A, Forbord S, Wang X, Broch OJ, Dahle SW, Størseth TR, et al. Seasonaland depth-dependent growth of cultivated kelp (Saccharina latissima) in close proximity to salmon (Salmo salar) aquaculture in Norway. Aquaculture 2013:414-415:191-201.

[61] Handå A, Min H, Wang X, Broch OJ, Reitan KI, Reinertsen H, et al. Incorporation of fish feed and growth of blue mussels (Mytilus edulis) in close proximity to salmon (Salmo salar) aquaculture: Implications for integrated multi-trophic aquaculture in Norwegian coastal waters. Aquaculture 2012;356-357:328-41.

[62] Buck BH, Berg-Pollack A, Assheuer J, Zielinski O, Kassen D. Technical realisation of extensive aquaculture constructions in offshore wind farms: consideration of the mechanical loads. In: Proceedings of the 25th International Conference on Offshore Mechanics and Arctic Engineering, OMAE 2006., Hamburg, Germany. Ocean, Offshore, and Arctic Engineering ASME. New York, NY: American Society of Mechanical Engineers; 4-9 June 2006. 